\title{
Acceptability of a Parental Early Warning Tool for Parents of Infants with Complex Congenital Heart Disease: A Qualitative Feasibility Study
}

Dr. Kerry Gaskin, Principal Lecturer in Advancing Clinical Practice, Nursing and Midwifery Department, Institute of Health \& Society, University of Worcester, Henwick Grove, Worcester WR26AJ

Kerry Gaskin ${ }^{1}$, Dr. Jo Wray², David Barron ${ }^{3}$

${ }^{1}$ Principal Lecturer in Advancing Clinical Practice, Nursing and Midwifery Department, Institute of Health \& Society, University of Worcester, Henwick Grove, Worcester WR26AJ

2 Senior Research Fellow in Health Psychology, Great Ormond Street Hospital NHS Foundation Trust, London UK WC1N

${ }^{3}$ Consultant Cardiac Surgeon, Cardiac Surgery Department, Birmingham Children's Hospital NHS Foundation Trust, Birmingham UK

\section{Acceptability of a parental early warning tool}

Key words: Cardiac Surgery, Monitoring, Qualitative Research, Nursing Care, Congenital Abnormalities

Word Count: 3007 


\begin{abstract}
Aim To explore the acceptability and feasibility of a parental early warning tool, called the Congenital Heart Assessment Tool (CHAT), for parents going home with their infant between first and second stage of surgery for complex congenital heart disease.

Background Home monitoring programmes were developed to aid early recognition of deterioration in fragile infants between first and second surgical stage. However, this necessitates good discharge preparation to enable parents to develop appropriate knowledge and understanding of signs of deterioration to look for and who to contact.

Design This was a longitudinal qualitative feasibility study, within a constructivist paradigm. Parents were taught how to use the CHAT before taking their infant home and asked to participate in semi-structured interviews at four timepoints: before discharge [T0]; two weeks after discharge [T1], eight weeks after discharge [T2] and after stage two surgery [T3]. Interviews were transcribed verbatim and thematically analysed.

Setting One tertiary children's cardiac centre in the UK

Subjects Twelve parents of eight infants who were discharged following first stage cardiac surgery for complex congenital heart disease, between August 2013 and February 2015

Results: Four main themes emerged: 1) parental preparation and vigilance; 2) usability; 3) mastery; 4) reassurance and support.

Conclusions: The study highlighted the benefit of appropriately preparing parents before discharge, using the CHAT, to enable identification of normal infant behaviour and to detect signs of clinical deterioration. The study also demonstrated the importance of providing parents with information about when and who to call for management advice and support.
\end{abstract}

\title{
Introduction
}

In the UK, congenital heart disease (CHD) occurs in approximately 6 per 1,000 births ${ }^{1}$. About half of the 5,000 babies born with CHD every year in the UK, have lifethreatening conditions requiring surgery and life-long follow-up². Improvements in surgical, medical and nursing care have resulted in a significant increase in survival rates over recent years ${ }^{3}$; however, the first year of life remains a critical time for infants with complex $\mathrm{CHD}^{1}$ with mortality after discharge estimated to be $3-5 \%{ }^{4}$. To reduce inter-stage mortality, home monitoring programmes have been implemented in many 
centres $^{5-9}$, however, effective assessment of the infant by parents is necessary. This is only achievable if parents fully understand their infant's CHD and the signs of deterioration to look out for ${ }^{10-12}$; are adequately prepared prior to discharge for their transition from hospital to home $\mathrm{e}^{10,13}$ and know who to contact for appropriate advice and support ${ }^{4,10,12}$. In response to this need, an early warning tool, the Congenital Heart Assessment Tool $(\mathrm{CHAT})^{10}$, was developed using the principles of paediatric early warning scores (PEWS) ${ }^{14-16}$ in 2012 by a group of clinicians, parents and CHD charity members.

The CHAT, based on a traffic light system is divided into three columns: green (low risk), amber (intermediate risk) and red (high risk) and can be individualised by including the Consultant's preferred parameters (e.g. oxygen saturations). Parents are taught to assess their infant's activity level, skin colour, breathing, circulation, feeding and weight and to decide actions based on the information in each of the three columns (See Table 1). A CHAT assessment of green indicates that parents can 'carry on as normal'; any sign in amber triggers a phone call to the ward to discuss management; any sign in the red column indicates the infant is seriously ill and parents are advised to phone for an ambulance (call 999) immediately ${ }^{10}$. 
Table 1 Congenital Heart Assessment Tool (CHAT)

\begin{tabular}{|c|c|c|c|}
\hline \multicolumn{4}{|c|}{$\begin{array}{c}\text { Congenital Heart Assessment Tool } \\
\text { Parent's Traffic Light System }\end{array}$} \\
\hline & Green - low risk & $\begin{array}{l}\text { Amber - Intermediate } \\
\text { Risk } \\
\text { A -if any of these } \\
\text { signs are present ring } \\
\text { for advice from Ward } \\
\text { (name ward) } \\
\text { If in doubt call } 999\end{array}$ & $\begin{array}{l}\text { Red- High Risk } \\
R \text { - if any of these } \\
\text { signs are present call } \\
\text { for an ambulance on } \\
999\end{array}$ \\
\hline Baby's Skin Colour & $\begin{array}{l}\text { Your baby's usual } \\
\text { colour of skin, tongue, } \\
\text { especially lips and } \\
\text { nails }\end{array}$ & $\begin{array}{l}\text { Bluer or paler than } \\
\text { usual, or mottled }\end{array}$ & $\begin{array}{l}\text { Very pale/bluer, very } \\
\text { mottled }\end{array}$ \\
\hline Baby's Activity & $\begin{array}{l}\text { Behaves normally } \\
\text { e.g. Content/smiles } \\
\text { Stays awake or } \\
\text { awakens quickly (as } \\
\text { normal) } \\
\text { Normal crying easily } \\
\text { resolved by e.g. } \\
\text { feeding, comfort, } \\
\text { nappy change etc }\end{array}$ & $\begin{array}{l}\text { Quieter than normal, } \\
\text { not feeding as normal } \\
\text { Sleeping more than } \\
\text { normal } \\
\text { Responding less during } \\
\text { normal activity } \\
\text { Slightly irritable }\end{array}$ & $\begin{array}{l}\text { Not responding to } \\
\text { normal activity } \\
\text { Does not wake or if } \\
\text { roused does not stay } \\
\text { awake } \\
\text { Weak, high-pitched or } \\
\text { continuous cry or no } \\
\text { crying at all }\end{array}$ \\
\hline Baby's breathing & $\begin{array}{l}\text { Usual breathing (rate, } \\
\text { rhythm and effort) for } \\
\text { your baby }\end{array}$ & $\begin{array}{l}\text { More breathless, faster } \\
\text { rate, working harder to } \\
\text { breath, noisier } \\
\text { breathing than normal } \\
\text { Sucking in skin below } \\
\text { ribs more than normal } \\
\text { Nasal flaring } \\
\text { Oxygen saturation } \\
\text { range (add individual } \\
\text { details) }\end{array}$ & $\begin{array}{l}\text { Very breathless } \\
\text { Struggling to breath } \\
\text { Exhausted } \\
\text { Very noisy breathing } \\
\text { (Grunting) } \\
\text { Very fast breathing or } \\
\text { very slow breathing } \\
\text { severe 'sucking in skin' } \\
\text { below ribs }\end{array}$ \\
\hline Baby's circulation & $\begin{array}{l}\text { Your baby's usual } \\
\text { colour and warmth of } \\
\text { hands and feet }\end{array}$ & $\begin{array}{l}\text { More sweaty or clammy } \\
\text { than usual } \\
\text { Cooler hands and feet } \\
\text { than usual and not } \\
\text { 'pinking back up' } \\
\text { Eyes, hand, feet and/or } \\
\text { tummy puffier/more } \\
\text { swollen than normal }\end{array}$ & $\begin{array}{l}\text { Very cold, sweaty or } \\
\text { clammy hands and feet } \\
\text { Unresponsive } \\
\text { Very puffy/ very } \\
\text { swollen eyes, hands, } \\
\text { feet or tummy }\end{array}$ \\
\hline Baby's Feeding & $\begin{array}{l}\text { Baby feeding normally } \\
\text { and regularly wet } \\
\text { nappies } \\
\text { Discharge feeding } \\
\text { regime: (add details) }\end{array}$ & $\begin{array}{l}\text { Any diarrhoea or } \\
\text { vomiting } \\
\text { Vomit after medications } \\
\text { Poor feeding or } \\
\text { struggling to feed (e.g. } \\
\text { reduced time on breast) } \\
\text { Not keeping feeds }\end{array}$ & $\begin{array}{l}\text { Completely off feeds - } \\
\text { not feeding at all } \\
\text { Dry nappies } \\
\text { Very sunken 'soft spot' }\end{array}$ \\
\hline
\end{tabular}




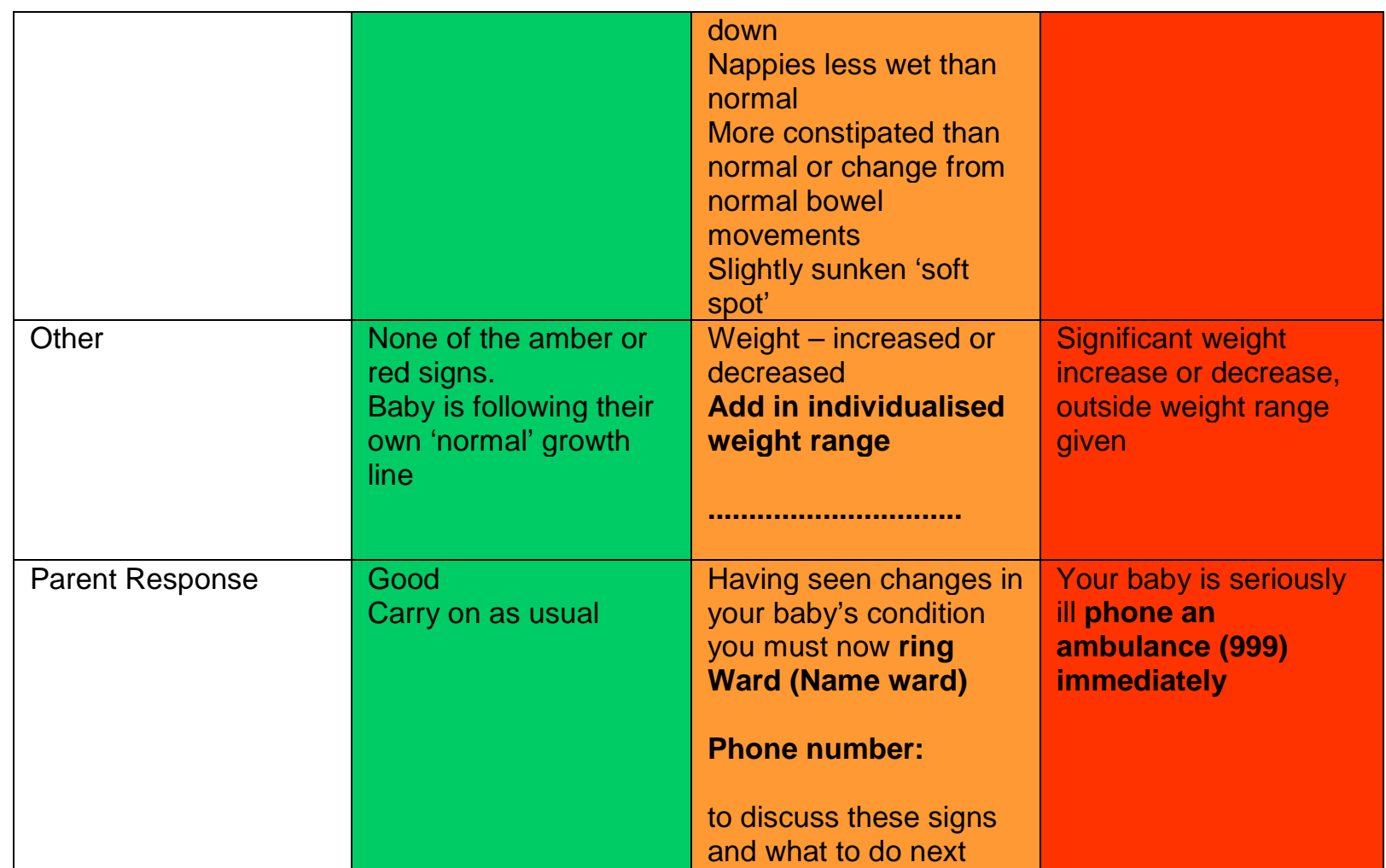

A traffic light system for parents to use at home, when assessing their infant's clinical condition, following first stage cardiac surgery for functionally univentricular heart or systemic shunt dependent lesion. Reprinted with permission ${ }^{10}$

Parent preparation before discharge ensures understanding of how to assess their infant daily or at any other time if their infant's condition had changed ${ }^{10}$, interpret the significance of the signs by using the CHAT; and record findings in a diary. Findings about the number of daily CHAT recordings, how warning signs were presented and the acceptability and feasibility of the CHAT for parents are presented in this manuscript.

\section{Design}

This longitudinal study was part of a mixed methods feasibility study ${ }^{10}$.A dialectical perspective ${ }^{17}$, in which both qualitative and quantitative data collection methods work 
together, was the best stance due to the underpinning epistemological assumptions of the study (interpretivism, constructivism and positivism), guiding each of the integral components. However, the interpretivist and constructivist paradigms were the dominant assumptions. Constructivist theory implies that humans try to make sense of the world that they are in; therefore, constructivism within the study explored the way parents independently made sense of their situations. Conversely, constructionism is socially constructed and considered the impact of culture and parents' social worlds (including the 'world' of being a parent of an infant with CHD) on the way they created and conveyed meaning ${ }^{18}$.

The study was undertaken at one UK specialist children's cardiac centre. Ethical approval was obtained from the National Research Ethics Committee West Midlands and Coventry University.

\section{Sampling strategy}

Parents were eligible to participate if their infant had undergone the first stage of cardiac surgery for complex CHD [functionally univentricular heart and systemic shunt dependent lesions] during the recruitment timeframe (August 2013 until February 2015); if they could read and understand English and could give informed consent. Screening was undertaken by the research nurse $(\mathrm{RN})$ in association with the clinical team daily (table 2). Eligible parents received an invitation letter and a Participant Information Leaflet and were given a minimum of 24 hours to consider their participation, before written consent was obtained. 
Table 2 Screening and recruitment

\begin{tabular}{|l|l|}
\hline Screening & Number \\
\hline Screened: infants had complex surgery during the recruitment phase & 80 \\
Ineligible: poor English requiring translation; or not discharged between & 19 \\
the two surgeries & 14 \\
Refused: lived too far away; 'too much going on'; child fostered; other & 15 \\
social issues & 19 \\
Missed: missed during study suspension*; missed as discharged over \\
the weekend
\end{tabular}

*Due to staffing issues the study had to be suspended for 3months

\section{Data collection, processing and analysis}

Parents were randomised, using computer generated randomisation, to one of three groups after consent was obtained. Group A parents were asked to measure and document their infant's oxygen saturations (Sp02) and weight daily, assess their infants using the CHAT tool and document this in their daily diary. Group B parents were asked to use the CHAT daily and document; and Group C parents had standard discharge care, without the equipment or CHAT. Unique identifier numbers ensured anonymity. Baseline birth and medical information (table 3) and parental demographics (table 4) were collected by the RN. Semi-structured interviews were conducted by the first author 
with parents in all three groups, at four timepoints: before discharge (T0); two weeks after discharge (T1); eight weeks after discharge (T2) and after stage two surgery (T3). Interviews at T0 were conducted face to face, to establish rapport with the family, subsequent interviews were conducted over the telephone. Couples were offered the opportunity to be interviewed either together or individually; T0 interviews were conducted with both parents in each couple. T1 interviews were conducted individually for two couples, due to one father's work commitments and one father declining further interviews.

Table 3 Infant's Birth and Medical Information (Groups A and B)

\begin{tabular}{|l|l|}
\hline Time of Diagnosis & Number of responses (n=8) \\
Antenatal & $6(100 \%)$ \\
\hline Female & $6(75 \%)$ \\
Male & $2(25 \%)$ \\
\hline Gestation (weeks) & $2(25 \%)$ \\
$<37$ weeks & $6(75 \%)$ \\
$>37$ weeks & \\
\hline Birth weight (Kg) & $4(50 \%)$ \\
$<3 \mathrm{Kg}$ & $3(37.5 \%)$ \\
$3.1-3.5 \mathrm{Kg}$ & $1(12.5 \%)$ \\
$4.1-4.5 \mathrm{Kg}$ & $6(75 \%)$ \\
\hline Diagnosis & $1(12.5 \%)$ \\
Hypoplastic Left Heart Syndrome & $1(12.5 \%)$ \\
Functionally univentricular heart & $3(37.5 \%)$ \\
Tetralogy of Fallot & $2(25 \%)$ \\
\hline Other non-cardiac defects & \\
\hline Genetic abnormality & $8(100 \%)$ \\
\hline Specialist Hospital Admission Route & \\
Retrieval team & $5(62.5 \%)$ \\
\hline Pre-operative management & $8(100 \%)$ \\
Mechanical ventilation & $4(50 \%)$ \\
Prostaglandin infusion & $5(62.5 \%)$ \\
\hline Inotropic support & \\
Treated acidosis & \\
\hline
\end{tabular}


Table 4 Parents' Demographics

\begin{tabular}{|c|c|c|}
\hline \multicolumn{3}{|c|}{ Parent Demographics at time of surgery (Groups A and B) } \\
\hline $\begin{array}{l}\text { Parent's Age } \\
<21 \\
21-25 \\
26-30 \\
31-40\end{array}$ & $\begin{array}{l}\text { Mother }(n=7) \\
1 \\
1 \\
2 \\
3\end{array}$ & $\begin{array}{l}\text { Father } \\
\text { (not available) }\end{array}$ \\
\hline $\begin{array}{l}\text { Employment } \\
\text { Employed for wages } \\
\text { Self-employed } \\
\text { A homemaker } \\
\text { Maternity/paternity leave }\end{array}$ & $\begin{array}{l}\text { Mother } \\
0 \\
1 \\
7 \\
0\end{array}$ & $\begin{array}{l}\text { Father } \\
5 \\
1 \\
1 \\
1\end{array}$ \\
\hline $\begin{array}{l}\text { Deprivation Index Score } \\
0-5,000 \text { (highest deprivation - top } 20 \%) \\
5,000-10,000 \\
10,000-15,000 \\
20,000-25,000 \text { (lowest deprivation - lowest } 20 \%)\end{array}$ & $\begin{array}{l}3 \\
1 \\
3 \\
1\end{array}$ & \\
\hline $\begin{array}{l}\text { Distance from Specialist Cardiac Hospital } \\
<20 \text { miles } \\
20-30 \text { miles } \\
30-40 \text { miles } \\
50-100 \text { miles } \\
>100 \text { miles }\end{array}$ & $\begin{array}{l}(n=8) \\
2 \\
1 \\
2 \\
2 \\
1\end{array}$ & \\
\hline $\begin{array}{l}\text { Ethnicity } \\
\text { White - British } \\
\text { White - European } \\
\text { Black or Black British } \\
\text { British Asian }\end{array}$ & $\begin{array}{l}\text { Mother } \\
6 \\
0 \\
2 \\
0\end{array}$ & $\begin{array}{l}\text { Father } \\
4 \\
1 \\
2 \\
1\end{array}$ \\
\hline
\end{tabular}

**The postcode deprivation index (index of multiple deprivation) was calculated online in 2013;

where a score of 1 was the most highly deprived area. This provided information about possible socioeconomic factors that might have impacted on the parents' experience.

An interview schedule (table 5) guided discovery of parents' experiences whilst allowing free description, follow up questions and probes. Interviews were audio recorded and 
transcribed verbatim. The Principal Investigator used the six phased thematic approach of Braun \& Clarke ${ }^{19}$ to analyse the data. The analysis was subsequently reviewed by the research team and any disagreements resolved by consensus. QRS NVivo10 software was used for data management.

Table 5 Interview questions

Parents were asked a range of questions at each time point relating to their experience of being in the study and using the CHAT tool.

Please can you tell me how you feel about being involved in the project?

Do you have any particular concerns or worries about being in the project?

Can you describe the preparation you had before discharge? Did you feel adequately prepared for going home? Can you tell me what you were told about the CHAT tool? How did you feel about using it?

Can you describe your experience of using the CHAT tool? (Prompts included asking how they used it, when, why, how they felt)

Thinking back to when you first went home, is there anything that you now think you should have been told but were not told?

How do you feel about recognising clinical deterioration in your baby using CHAT Any other comments?

Criteria were employed to address trustworthiness ${ }^{20}$ including triangulation with other data collected in the feasibility study; maintaining an audit trail; keeping field notes and reflective notes. Only staff at the study centre had access to additional personal data. The PI only had access to parents' first names and telephone numbers. Data were retained in accordance with Coventry University's policy on Academic Integrity. 


\section{Findings}

Eighty infants were screened during the recruitment period, of whom 47 were eligible for participation (Table 2) with parents of 13 infants recruited (Group A =5; Group B = 4, Group $C=4)$. Parents of 8 infants (8 mothers, 4 fathers) from Groups $A(n=4)$ and B $(n=4)$ took part in the interviews and were asked about the CHAT. Other interview findings are presented elsewhere ${ }^{21}$. The data set reported here included 22 interviews, lasting from 9.49 - 59.29 minutes, totaling 486.44 hours. Not all parents completed all four interviews due to their infant being readmitted to hospital, not being contactable, or not returning calls. The time from discharge to readmission (T0 to T3) varied amongst participants, ranging from 62-228 days (median $=151 ;$ mean $=145.6 ;$ S.D. $=61.6$ ), but all infants survived the first two stages of surgery.

CHAT Recordings:

Six families documented the CHAT measurements in their daily diary (see Table 6). None of the families recorded their CHAT assessment every day, because of 'increasing confidence over time', 'being too busy with their infant's normal care' and 'feeling burdened'. 
Table 6 Number of daily measurements recorded in the daily diary and interview completion (Groups A, B)

\begin{tabular}{|c|c|c|c|c|c|c|c|}
\hline Group & $\begin{array}{l}\text { Green } \\
\text { (days) }\end{array}$ & $\begin{array}{l}\text { Amber } \\
\text { (days) }\end{array}$ & $\begin{array}{l}\text { Red } \\
\text { (days) }\end{array}$ & $\begin{array}{l}\text { Time } \\
\text { between } \\
\text { stage } 1 \text { \& } \\
2 \text { surgery } \\
\text { (days) }\end{array}$ & $\begin{array}{l}\text { Time at } \\
\text { home } \\
\text { (days) }\end{array}$ & $\begin{array}{l}\text { Total diary } \\
\text { entries } \\
\text { (days) }\end{array}$ & $\begin{array}{l}\text { Interview } \\
\text { completion }\end{array}$ \\
\hline$A(1)$ & 30 & 0 & 1 & 32 & 31 & $31(100 \%)$ & $\begin{array}{l}\text { Mother T0, } \\
\text { T1, T3 }\end{array}$ \\
\hline$A(2)$ & 13 & 1 & 0 & 197 & 174 & $14(8 \%)$ & $\begin{array}{l}\text { Mother all } \\
\text { Father T1 }\end{array}$ \\
\hline A (3) & 53 & 0 & 0 & 251 & 200 & $53(26.5 \%)$ & $\begin{array}{l}\text { Mother all } \\
\text { Father all }\end{array}$ \\
\hline A (4) & 0 & 0 & 0 & 154 & & 0 & $\begin{array}{l}\text { Mother T1, } \\
\text { T3 }\end{array}$ \\
\hline B (1) & 40 & 2 & 0 & 136 & 123 & 42 (34\%) & $\begin{array}{l}\text { Mother all } \\
\text { Father all }\end{array}$ \\
\hline B (2) & 14 & 1 & 0 & 190 & 164 & $15(9 \%)$ & $\begin{array}{l}\text { Mother T0, } \\
\text { T1, T2 }\end{array}$ \\
\hline B (3) & 84 & 3 & 0 & 120 & 102 & 87 (85\%) & $\begin{array}{l}\text { Mother all } \\
\text { Father all }\end{array}$ \\
\hline B (4) & 0 & 0 & 0 & 93 & & 0 & Mother T1 \\
\hline
\end{tabular}

Ward staff were asked to document calls from parents during the study, information was not recorded for all CHAT triggers in the ward documentation but was available in interview transcripts (see Table 7). 
Table 7 CHAT Triggers (Group A, B) and Recorded Contact with Health Care

Professionals (Group A, B, C)

\begin{tabular}{|c|c|c|c|c|c|}
\hline Participant & $\begin{array}{l}\text { Number of } \\
\text { contacts made }\end{array}$ & Contact with & Reason & Advice & Outcome \\
\hline \multirow[t]{2}{*}{$A(1)$} & \multirow[t]{2}{*}{1} & Phoned 999 & $\begin{array}{l}\text { Triggered red on } \\
\text { CHAT, } \\
\text { struggling to } \\
\text { breath }\end{array}$ & $\begin{array}{l}\text { Admitted to } \\
\text { local hospital }\end{array}$ & $\begin{array}{l}\text { Discharged } \\
\text { the next day }\end{array}$ \\
\hline & & \multicolumn{4}{|c|}{ OPA SpO2 dropped admitted to the ward and kept in until stage 2} \\
\hline \multirow[t]{2}{*}{$A(2)$} & \multirow[t]{2}{*}{1} & Ward & $\begin{array}{l}\text { Vomiting and } \\
\text { sticky eyes }\end{array}$ & $\begin{array}{l}\text { Bathe eyes } \\
\text { and observe } \\
\text { feeding } \\
\text { Attend GP }\end{array}$ & $\begin{array}{l}\text { GP no } \\
\text { medication } \\
\text { given, } \\
\text { advised to } \\
\text { clean with } \\
\text { sterile water }\end{array}$ \\
\hline & & \multicolumn{4}{|c|}{ Admitted to ward following MRI, Discharged } \\
\hline$A(3)$ & 1 & Ward & $\begin{array}{l}\text { Advice re NGT } \\
\text { (documented in } \\
\text { interview } \\
\text { transcript, not } \\
\text { CHAT diary) }\end{array}$ & $\begin{array}{l}\text { Not } \\
\text { documented }\end{array}$ & $\begin{array}{l}\text { Not } \\
\text { documented }\end{array}$ \\
\hline A (4) & 0 & 0 & 0 & 0 & 0 \\
\hline \multirow[t]{3}{*}{$\mathrm{B}(1)$} & \multirow[t]{3}{*}{3} & Routine OPA & $\begin{array}{l}\text { Triggered amber } \\
\text { on CHAT but } \\
\text { was booked for } \\
\text { OPA that day } \\
\text { anyway } \\
\text { SpO2 lower } \\
\text { than normal and } \\
\text { pale }\end{array}$ & Seen by $\mathrm{Dr}$ & $\begin{array}{l}\text { No medical } \\
\text { concerns }\end{array}$ \\
\hline & & Went to GP & $\begin{array}{l}\text { Amber trigger } \\
\text { on CHAT } \\
\text { Subcostal } \\
\text { recession }\end{array}$ & Seen by GP & $\begin{array}{l}\text { No medical } \\
\text { concerns }\end{array}$ \\
\hline & & $\begin{array}{l}\text { Routine OPA } \\
\text { for } E C H O\end{array}$ & $\begin{array}{l}\text { Amber trigger } \\
\text { on CHAT but } \\
\text { booked in for } \\
\text { OPA anyway } \\
\text { Pale, feeding }\end{array}$ & Seen by $\mathrm{Dr}$ & $\begin{array}{l}\text { No medical } \\
\text { concerns }\end{array}$ \\
\hline
\end{tabular}




\begin{tabular}{|c|c|c|c|c|c|}
\hline & & & $\begin{array}{l}\text { less, sleeping } \\
\text { more }\end{array}$ & & \\
\hline & & Planned admiss & on for cardiac cath & terisation, kept ir & for Stage 2 \\
\hline $\mathrm{B}(2)$ & 1 & Ward & $\begin{array}{l}\text { Amber triggered } \\
\text { Nappy }\end{array}$ & $\begin{array}{l}\text { Not } \\
\text { documented }\end{array}$ & $\begin{array}{l}\text { Not } \\
\text { documented }\end{array}$ \\
\hline B (3) & 3 & Ward & $\begin{array}{l}\text { Amber trigger } \\
\text { on CHAT } \\
\text { Sunken } \\
\text { fontanelle }\end{array}$ & $\begin{array}{l}\text { Contact GP if } \\
\text { worsens }\end{array}$ & \\
\hline & & Ward & $\begin{array}{l}\text { Amber triggered } \\
\text { on a few things } \\
\text { Increased } \\
\text { respiratory } \\
\text { effort, feeding } \\
\text { reduced }\end{array}$ & $\begin{array}{l}\text { Contact local } \\
\text { hospital }\end{array}$ & $\begin{array}{l}\text { Admitted to } \\
\text { local hospital } \\
\text { overnight }\end{array}$ \\
\hline & & $\begin{array}{l}\text { Took straight to } \\
\text { local A \& E }\end{array}$ & $\begin{array}{l}\text { Didn't use } \\
\text { CHAT } \\
\text { Bronchiolitis }\end{array}$ & $\begin{array}{l}\text { Kept in } \\
\text { overnight }\end{array}$ & \\
\hline B (4) & & rded in daily diar & and only pre-discl & arge interview & \\
\hline$C(1)$ & 0 & & & & \\
\hline$C(2)$ & 4 & 2x Ward & $\begin{array}{l}\text { Called for } \\
\text { advice } \\
\text { (interview } \\
\text { transcript) }\end{array}$ & $\begin{array}{l}\text { Not } \\
\text { documented }\end{array}$ & \\
\hline & & $\begin{array}{l}\text { Attended local } \\
\text { PAU }\end{array}$ & Vomiting & $\begin{array}{l}\text { Observation } \\
\text { on unit for } 8 \\
\text { hours }\end{array}$ & discharged \\
\hline & & Called 999 & $\begin{array}{l}\text { Choking, sick, } \\
\text { blue }\end{array}$ & ED for 2 hours & $\begin{array}{l}\text { Discharged } \\
\text { home }\end{array}$ \\
\hline C (3) & & d home & & & \\
\hline$C(4)$ & 1 & Ward & $\begin{array}{l}\text { Called for advice } \\
\text { (interview } \\
\text { transcript) }\end{array}$ & $\begin{array}{l}\text { Not } \\
\text { documented }\end{array}$ & \\
\hline
\end{tabular}


Interviews:

Four themes emerged from the interviews: 1) parental preparation and vigilance; 2) usability; 3) mastery; 4) reassurance and support.

\section{1) Parental preparation and vigilance}

Before discharge all parents perceived that being taught how to use the CHAT helped them to prepare for going home and to be vigilant; one father said it has "given us the main tools to survive with; if something happens I'll know what I need to do". Another parent (mother) said: "I feel good, because I know, because I'm with [infant] everyday, [have been looking at the CHAT everyday whilst in hospital] I know when [infant]'s poorly, I know when [infant]'s in green, when [infant]'s in amber and when to call 999". Another mother commented "it's good [CHAT] it's prepared us a lot for things that we wouldn't have been prepared for if we weren't in the programme".

Some parents felt that the CHAT gave them the confidence to make the right decision "If we didn't have it [CHAT] we'd have to be making our own judgement [it] could probably not be the right one". At T1, all but one of the parents felt that they were well prepared and that they were gaining confidence in recognising signs of deterioration by using the CHAT. One mother said "I'm not very confident with it but ... [RN] said she'd just go through what l'd done and make sure I'm on track". Conversely, another mother said that "It's really helpful because it tells you what to look for in green, amber and red. If I didn't have the CHAT to look at when [infant] was poorly the other night, I would have gone running straight into hospital; I wouldn't have known what to tell the doctor 
when I phoned up [the CHAT triggered Amber]. It's really helpful. It's helping me to describe what I'm seeing"

\section{2) Usability}

After discharge, most parents began to perceive an increase in confidence in terms of recognising what were normal signs for their infant. One mother explained "it [CHAT] is easy to use but I'll be honest I don't use it every day .... sometimes I forget, but if there's a problem with her it's the first thing I pick up, I don't really use it when everything's fine anyway".

In addition to feeling that they were well prepared for discharge, most parents' comments at T1, focused on the ease of using the CHAT at home. One father said "I enjoy the CHAT and I enjoy the diary thing, I think that's very good and I'm really appreciative of it because it does put you at ease knowing that you've got everything written in the diary as well". Another father explained "it's pretty straightforward with what signs you've got to look for and you know what to do if you see the signs so, yeah, it's pretty helpful". Conversely his wife described feeling unsure of how to use the CHAT (quote above),but was overwhelmed with the transition of going home and had arranged to receive further training from the $\mathrm{RN}$ at the outpatient's appointment the following week. At the final interview this mother evaluated the CHAT saying: "Reading through the coloured chart helped me to decide whether to get help or not, so I did find it useful from that point of view. There were just a couple of times that I phoned through. Having that to refer to just to double check things, it did help. [The CHAT] was easy enough to use, I wouldn't say there was anything to change. It seemed to work". 


\section{3) Mastery}

All parents used the CHAT daily when they were first discharged, to assess their infant. However, over time some parents gained mastery in terms of knowing what was normal for their infant and recognising when something was different. At this point these parents stopped using the CHAT and recording daily and began using it only when something changed. For example, one mother explained: "we did [use the CHAT] when we first came out because we were nervous and we needed it to help us .....now we feel confident enough that we know the signs to check for and the traffic light system ourselves and kind of know where it would be in the book". One mother explained how (at T2) the tool was just there to 'give them a boost'. They felt that the tool was a 'really big help' when they were first discharged and because they used the CHAT daily at the start they felt reassured that they were doing the right things "but now it's made us more confident because we've had that chart to start off with and to reassure us if we were doing the right thing or not".

Conversely, for some parents, continuing daily assessment helped them to feel more confident throughout their time at home with their infant, as this quote (at T2) demonstrates: "I go through it every day and check [infant] against it. I think it helps me to pinpoint what's right and wrong. It definitely makes me [feel more confident] if I didn't have it as a backup l'd be panicking about everything and l'd be constantly ringing the hospital." 


\section{4) Reassurance and support}

Parents also described how the CHAT had reassured them to articulate their concerns at the appropriate time and to the appropriate person. One father said "you look at her and you go through all of them CHATs and you go right ok yes, if I have any worries I go to amber and then you can ring somebody up to talk to somebody".

Being able to talk to the specialist team directly for an amber trigger reduced pressure on parents, reducing the need to provide an explanation of their infant's cardiac condition to someone that did not understand. Parents perceived this as a positive aspect of support. One mother said: "it does give you a lot of reassurance, obviously being able to phone the ward when it is in an amber state, having them reassure you and tell you what to do, it's very helpful. Because obviously if that's the case like an amber alert I would normally phone 111 the NHS service and then you'd have to explain what the condition is and not having to go through all of that, it again alleviates some of the pressure".

\section{Discussion}

This study reports on the feasibility of the CHAT, which we believe is the first tool to be developed specifically for parents of fragile babies going home with their infant after the first stage of complex cardiac surgery. The main finding was a parental perception that early assessment of their infant was feasible using the CHAT, despite parents not documenting the results for the whole of their stay at home between stage 1 and 2 of 
surgery. The CHAT was described as useful in preparing them for discharge; easy to use at home and reassuring. None of the parents gave any negative comments about the CHAT. Parents also perceived that the CHAT had increased their confidence in looking after their infant at home. Several families described how they felt informed by learning how to use the CHAT before discharge. Additionally, following an amber or red trigger of CHAT, parents felt able to make early decisions regarding accessing advice and treatment and articulating their concerns to health care professionals. These findings suggest that parents benefited from a greater understanding of their infant's condition before going home, by being taught signs of deterioration to look out for using the CHAT; being given a checklist and a formalised route to seek professional help. Parents also commented on the fact that their increasing confidence meant that they knew what was normal (green) and no longer needed to use the CHAT on a daily basis, but had the tool available to refer to if their infant's signs changed.

The CHAT was developed to enhance communication, using the principles of a traffic light system ${ }^{26}$ and meeting the recommendations of other studies ${ }^{4,22-25}$. The CHAT has contributed to practice by creating an effective discharge information and preparation tool to ensure that parents have the appropriate knowledge, understanding and skills to care for their fragile infant at home. However, mechanisms for sharing information with professionals outside the tertiary centre need improving ${ }^{27}$ primary care and local community teams need individualised information, with expected clinical parameters, upon which to make decisions. Parental dissatisfaction with the information that they receive has been previously identified, ${ }^{22-25}$ indicating the need for standardised and 
structured handover documentation to reduce the deficits in communication and information transfer at discharge ${ }^{4}$. Furthermore, for discharge preparation to be successful, professionals working within the congenital heart network ${ }^{28}$, need appropriate skills and knowledge about complex CHD to teach parents about their infant's condition and how to spot signs of deterioration. This study also found that professionals need to be more effective at documenting telephone calls with families and the advice given, to ensure effective ongoing management of parents' concerns and their infant's condition.

An important issue preventing participation in the study was parents' psychological functioning. Some particularly anxious parents expressed feeling emotionally unable to take part; professionals need to consider the psychological impact of having a fragile infant and the affect on understanding during discharge preparation and vigilance at home. Another factor impacting on recruitment was the limited understanding of written and spoken English language for some parents. Ethnicity has previously been linked to adverse outcomes for infants with $\mathrm{CHD}^{29}$. However, a more recent UK study ${ }^{4}$ found that the group labelled 'other' (including Far East, Middle East and North Africa) were at greater risk, perhaps reflecting contemporary migration changes. Future studies need to consider the varied population and language requirements of parents whose infants require cardiac surgery in the UK and address the cultural and language implications of translating the tool into other languages.

\section{Conclusion}


This study demonstrated that the CHAT was accessible and feasible for this group of parents. It enhanced discharge education by enabling greater confidence in knowing the signs of deterioration to look for, whilst reassuring and supporting them in contacting the relevant specialist team for advice. Further evaluation of the CHAT and its effectiveness is currently underway with a larger sample. A nationally standardised discharge package, including CHAT for parents of infants with a functionally univentricular heart, is currently being developed in the UK. Furthermore, the CHAT could be beneficial for local and community teams, who may have limited expertise in neonatal cardiac surgery and require guidance regarding specialist advice.

What is already known on this topic:

- Infants requiring complex cardiac surgery in the early neonatal period are vulnerable to sudden deterioration between the first and second stage of surgery

- Formal home monitoring of oxygen saturations and weight can help identify 'at risk' infants, however availability of home monitoring programmes is variable across the UK

- It is essential that parents can recognise signs of deterioration promptly to initiate timely decisions and early intervention by specialist health care professionals

What this study adds

- Use of a structured assessment tool, including assessment of their infant's activity and behaviour, can assist parents to identify signs of deterioration 
- Pre-discharge preparation using a traffic light system can assist parents to gain confidence in their ability to assess their infant for signs of deterioration

- A structured tool can empower parents to clearly articulate their infant's needs and their concerns in a timely manner to the appropriate health care professionals

\section{Acknowledgements:}

Dr. Kerry Gaskin (Principal Investigator); Mr. David Barron, Chief Clinical Investigator [Research Team]; Suzie Hutchinson, CEO, Isabel Baumber \& Rachel Robinson, Parent Members, Little Hearts Matter; Amanda Daniels, Advanced Nurse Practitioner; Gill Harte, Children's Cardiac Clinical Nurse Specialist; Dr. Jo Wray, Senior Research Fellow, made substantial contributions to the development of the CHAT, design of the study and were members of the External Advisory Group throughout the study.

Professor Gill Furze and Dr Tim Kilner, Coventry University PhD Supervisory Team, contributed to the design of the feasibility study and preparation for ethical approval. $\mathrm{Dr}$ Charlotte Hilton joined the Supervisory team in 2013. Kim Jones, Lucy Cooper, Melanie Rooney, Needa Mohammed, Research Nurses; recruited parents, obtained consent, prepared parents for discharge, collected and analysed data. They are aware of the decision to publish this paper but did not contribute to the content. 
Dr. Kerry Gaskin (Principal Investigator) was the main author; Dr. Jo Wray and Mr. David Barron (Chief Clinical Investigator) contributed to the content, reviewed and revised this paper for submission

\section{Competing Interests: None}

Funding: Heart Research UK funded the Research Nurse post (0.6WTE) and the equipment (10 pulse oximeters and 10 digital scales) for the Feasibility Study.

The team acknowledge support of NIHR through the Comprehensive Clinical Research Network, as the feasibility study was adopted to the NIHR portfolio

Ethics: Ethical approval was given by the National Research Ethics Committee West Midlands, Solihull; Coventry University Ethics Committee (as sponsors) and the local Research and Development Team at the Study Site.

\section{References}

1. Townsend N, Bhatnagar $\mathrm{P}$, Wickramasinghe $\mathrm{K}$, et al. Children and young people statistics 2013. London. British Heart Foundation.

2. Congenital Heart Disease Working Group. Cardio and Vascular Coalition (CVC) Briefing Paper. Congenital Heart Disease 2008 https://www.bhf.org.uk/getinvolved/campaigning/cardio-and-vascular-coalition (accessed January 2017)

3. Department of Health Adult Congenital Heart Disease. A Commissioning Guide. 2006. London. DH.

4. Crowe S, Ridout DA, Knowles R, et al. Death and Emergency Readmission of Infants Discharged After Interventions for Congenital Heart Disease: A National 
Study of 7643 Infants to Inform Service Improvement. Journal of the American Heart Association,2016;5(5): e003369.

5. Ghanayem NS, Hoffman GM, Mussatto KA, et al. Home surveillance program prevents interstage mortality after the Norwood procedure. The Journal of thoracic and cardiovascular surgery 2003;126(5):1367-1375.

6. Fenton KN, Pigula FA, Gandhi, et al. Interim mortality in pulmonary atresia with intact ventricular septum. The Annals of thoracic surgery2004:78(6),1994-1998.

7. Ghanayem, N.S., Cava, J.R., Jaquiss, R.D. et al. Home monitoring of infants after stage one palliation for hypoplastic left heart syndrome. In Seminars in Thoracic and Cardiovascular Surgery: Pediatric Cardiac Surgery Annual 2004;7(1)32-38.

8. Ghanayem NS, Tweddell JS, Hoffman GM, et al. Optimal timing of the second stage of palliation for hypoplastic left heart syndrome facilitated through home monitoring, and the results of early cavopulmonary anastomosis. Cardiology in the Young 2006;16(S1):61-66.

9. Steury R, Cross R, Colyer J, et al. Automated Home Monitoring of Infants after Stage I Palliation of Single Ventricle Physiology: Is it Feasible? Circulation 2010;122 (Suppl 21):A12371-A12371.

10. Gaskin KL, Barron D, Daniels A. Parents' preparedness for their infants' discharge following first-stage cardiac surgery: development of a parental early warning tool. Cardiology in the Young DOI:

https://doi.org/10.1017/S1047951116001062 [published online first 19July2016] 
11. Staveski SL, Zhelva B, Paul R, et al. Pediatric Cardiac Surgery Parent Education Discharge Instruction (PEDI) Program A Pilot Study. World Journal for Pediatric and Congenital Heart Surgery, 2015;6(1):18-25.

12. Tregay J, Wray J, Bull C, et al. Unexpected deaths and unplanned re-admissions in infants discharged home after cardiac surgery: a systematic review of potential risk factors. Cardiology in the Young, 2015;25(05):839-852.

13. Jones T, Cook K, Crook R, et al. 'Treatment Options and Management' In Cook K, Langton H, Cardiothoracic Care for Children and Young People. A Multidisciplinary Approach. Oxford: Wiley-Blackwell 2009:63-123

14. Haines C. Acutely ill children within ward areas - care provision and possible development strategies, Nursing in Critical Care 2005;10(2):98-104

15. Akre M, Finkelstein M, Erickson M, et al. Sensitivity of the Pediatric Early Warning Score to Identify Patient Deterioration, Pediatrics 2010;125(4):e763-769

16. Parshuram CS, Bayliss A, Reamer J, et al. Implementing the Bedside Paediatric Early Warning Sytem in a community hospital: A prospective observational study, Paediatrics and Child Health, 2011;16(3):e18-22

17. Greene, J.C. and Caracelli, V.J. (1997) Defining and describing the Paradigm Issue in MixedMethod Evaluation, New Directions for Evaluation 74: 5-17

18. Crotty, M. (1998) The Foundations of Social Research. Meaning and Perspective in the Research Process. London. Sage.

19. Braun V, Clarke V. Using thematic analysis in psychology, Qualitative Research in Psychology 2006;3:77-101

20. Guba EG. Criteria for assessing the trustworthiness of naturalistic inquiries, Educational Communication and Technology Journal 1981;28:75-91 
21. Gaskin KL (2017) Patterns of transition experience for parents going home from hospital with their infant after first stage surgery for complex congenital heart disease. Journal of Pediatric Nursing. In Press. Available online 6 December 2017 http://www.pediatricnursing.org/article/S0882-5963(17)30521-3/fulltext

22. Kosta L, Harms L, Franich-Ray C, et al. Parental experiences of their infant's hospitalization for cardiac surgery, Child Health Care Development doi:10.1111/cch.12230 [Epub ahead of print 2015].

23. Arya B, Glickstein JS, Levasseur SM, et al. Parents of Children with Congenital Heart Disease Prefer More Information Than Cardiologists Provide, Congenital Heart Disease 2013;8:78-85

24. Twaddell JW. Parent education needs of infants with complex life-threatening illnesses. Unpublished PhD Thesis. The University of North Carolina at Greensboro,2015

https://libres.uncg.edu/ir/uncg/f/Twaddell uncg 0154D 11155.pdf (accessed 31 ${ }^{\text {st }}$ January 2017)

25. Little Hearts Matter, 2013 Membership Questionnaire [online] 2015.http://www.Ihm.org.uk/Upload/Publications/2013\%20membership\%20questi onnaire.pdf (accessed 31 $1^{\text {st }}$ January 2017)

26. National Institute for Health and Care Excellence. Fever in the Under 5s: assessment and initial management [online] 2013,. https://www.nice.org.uk/guidance/cg160 (accessed 31st January 2017) 
27. Tregay J, Wray J, Crowe S, et al (2016) Going home after infant cardiac surgery: a UK qualitative study, Archives of Disease in Childhood Published Online First: 29 January 2016. doi: 10.1136/archdischild-2015-308827

28. NHS England. CHD Standards and Service Specification [online] 2016 https://www.england.nhs.uk/commissioning/wp-

content/uploads/sites/12/2016/03/chd-spec-standards-2016.pdf (accessed 31st January 2017)

29. Sheridan E, Wright J, Small N, et al. Risk factors for congenital anomaly in a multiethnic birth cohort: an analysis of the Born in Bradford study. Lancet. 2013;382:1350-1359 
